DEPARTMENT OF COMERCE

WASHINGTON, D. C.

COMMERCIAL STANDARDS MONTHLY

Wonthly News Bulletin of Commercial Standaras Group, Bureau of Standards.

\section{SIMPLIFIED_PRACIICE}

Balancing

Better Management.

Li ision liews

liotor Truck Simplification

Post Office Saves $\$ 45,000$.

Results and Benefits.

Simplified Invoice League.

Stabilization.

The Great Adventure

Use of Simplified Practice News.

COMERCIAL STANDARDS

News of Prozress.

\section{SPECIFICATIONS}

Proclirement Specifications

Salvage.

Standard Equipment

\section{MARINE STANCARES}

Committee News.

Editorial Praise

COMESTIC COMMERCE

Advantages of Packaged Merchandise..

Eill of Lading.

Electrical Appliance Market.

Textile Publications Listed.....

Trade-In Furniture Plan

\section{BUILEING AND HOUSING}

5 Plumbing Legislation

RESEAP.CH

Establishes Research Bureau............. 24

Hidden Treasure.......................... 27

Industrial Tool ............................... 29

Market Research Agencies................. 30

6 Research and Advertising................. 25

3 Research as a Business Help............. 23

Vision......................................... 26

What Does the Buyer Want?............... 28

11 UTILIZATION OF WASTE

Waste Pays in Some Ways

13 ELIMINATION OF WASTE

12

14 Booklet on Lumber............................ 35

Look Back-Ahead............................ 32

Reduction of Waste.......................... 33

Urges Waste Reduction...................... 34

15

16 N.EW PUBLICATIONS ........................... 36

APPENDIX ................................... 37

20

21

19

17

18

ADDRESS INQUIRIES TO "COMMERCIAL STANDARDS"

ROOM 316 COMMERCE BUILDING.

WASHINGTON, D. C. 

Commeroial Standards Monthly - No. $47-1-$

1. RESULTS AND EENEFITS OF APPLYING SIMPLIFIED PRACTICE TO FILES AND RASPS.

The Division of Simplified Practice has just made available the results of a survey to determine the benefits which followed the simplification of files and rasps.

For many years prior to the World War the manufacturers of files and rasps ha $i$ been making their product in an excessive variety of sizes and styles. During 1918 the Conservation Division of the War Industries Bcard in cooperation with the manufacturers discovered that no less than 1,351 varieties were then being offered to the trade and that less than half of these rould meet normal demands. The necessities of war made it imperative that all possible economies be strictiy observed to the end that no material nor human enerey be wasted. The Ccnservation Division therefore, effected an elimination of 732 of these unrecessary items, the marufacture and distribution of which was costing the industry much roney and effort in the form of excessive inventories of raw and finished materials, storage and handling, seling expense, etc.

After the war was ended and the War Industries Board dissolved, the manufacturers cooperated with the then newly created Division of Simplified Practice to further reduce the varieties of their product. The present simplified Practice Recommendation which resulted contains only 848 varieties of files and rasps and constitutes an elimination of 867 of the original 1351 sizes and types.

Five years have elapsed since the recommendation went into effect. In answer to the question - "Has the application of this simplified practice been beneficial to the industry?, the following facts are of interest.

A survey of production conducted by the division in 1927 showed that during the year of 1926. 93\% of the total volume, of producers who had accepted the recommenciation, was in the standard sizes and types comprising the simplified list. The question as to whether the demand for the non-standard items was sufficient to warrant including them in the recomendation was answered, - No. Four of the seven nanufacturers included declared that consumer demand indicated that further elimination could advantageously be effected.

Several months ago the Division addressed a request to all the acceptors of the recommendation asking the to evaluate the benerits of this simplified practice. One manufacturer said that since adopting the simplified practice recommendation his busiress has increased in volume $33.3 \%$ and that volume of inventory had decreased 25\%. Another said his sales had increased $23.5 \%$ while inventory decreased $35 \%$. Benefits such as reduced investment in dies, reduced inventory investment, quicker turnover, and better control of production, were also cited.

Distributors have berefitteu through dec reased inventory investment, quicker turnover, refuced storage requirements, and better service from the manufacturer.

Users are benefitting through quicker servico, but no coubt their most outstanding benefit is the protection that simplified practice affords against the innumerable whims and fancies of those who feel they must have special sizes or cuts of files rather than the standard $i t \in$ m. The standing committee's survey showed that out of the seven manufacturers, six enswered "yes" to the question - "Is there a price difrerential favoring the simplified lines as agairst non-standard itoms:" This means that under simplified practice the old system of spreading the extra cost of producing specials over the whole line and making the buyer of stardare items help pay the additonal expense involved, has been to a large extent. discontinlied. 



\title{
SIMPLIFIED PRACTICE
}

\author{
Edwin W. Ely.
}

\section{DIVISION_NEWS}

Manufacturers depend not alone upon rapid turn-over of goods for their profits. We are prone to confine our conception of turn-over to the products themselves whereas we should give some thought to the flexibility of the financial structure as well. That is, the turn-over of working capital. If the commodities a manufacturer passes on to his jobbers, wholesalers and retailers have been produced for a market that has been thoroughly analyzed as to demand, the chances for quick payment of bills are increased and consequent reinvestment of funds is assured.

Lack of capital is not always the true cause of manufacturers' ills. Lack of fluid capital, or "ready money" is often the true diagnosis. Industry has found that the intelligent application of the principles of Simplified Practice in business hastens physical turnover and quickens the flow of "ready money."

\section{Floor Sweeps.}

The Division wishes to announce that the individual companies and groups that have indicated their approval of Simplified Practice Recormendation No. 88. Floor Sweeps, represent the opinion of those who are concerned mith at least 80 per cent of the volume of this commodity. The effective date for the program is January 1, 1929, and it will sustain annuad revision.

\section{Bottles for Carbonated Beverages.}

A number of bottle manufacturers have submitted to this Division their contribution tc a consolidated report showing the relative demand for the various sizes and capacities of carbonated beverage bottles now being used. The data thus compiled will be used by the in dustry as a basis for a simplified practice recommendation covering bottle heights, capacities, diameters, and weights of glass.

\section{Glass_Containers for_Drugs.}

A sub-comittee, which was appointed by the chairman of the joint simplified practice committee of the Association at a meeting held on December 13, is now working on the preparation of a suitable questionnaire which is to be sent out in the near future to manufacturers of bottles for data which can be used as a basis for the development of a definite simplified practice recommendation for stock bottles and jars used in the drug and pharmaceutical industries. This survey has the support of the Glass Container Association, the American Hospital Association, and all the National drug and pharmaceutical Associations.

0live Jars.

The Division is in receipt of a number of letters from olive packers indicating that there are entirely too many varieties of bottles used for packing olives. It is the belief of the olive packers that a simplification program. similar to that recently dovelopod fo preserve jars and jelly glasses, would be entirely practicable. 

Commercial Standards Monthly - No. $47-3-$

Pickle_.ja․ $\underline{\text { s }}$.

It is the opinion of the pickle industry that some concerted action should be taken toward the simpification of glass containurs used in packing pickles and condiments. Towards that end the cooperation of the Division has been requested.

Hospital 1 Plum ing Fixtures.

At the request of the American Hospital Association, the Division is arranging for a preliminary conference to be held in Chicago. Illinois, on February 20th, to complete the formulation of a tentative simplified stock list of hospital pluming fixtures. Representatives of the fixture manufacturers, architects and hospital consultants have united to participate in the discussion. A general conference of manufacturers, distributors, and users of hospital plumbing fixtures will ultimately be called to draft a final simplified practice recommendation for the guidance of all concerned.

Glass Containers for Preserves, Jellies and Apple Butter.

At the January meeting of the National Preservers' Association, in Chicago, Illinois, announcement was made by a representative of the Division that surficient acceptances had been received to justify the final publication of Simplified Practice Recommendation \#9l, Preserve Jars, jelly Glasses, and Apple Butter Jars. The recomendation became effective January 1, 1928, for new prodiction; and January I, 1929 for spot stocks.

\section{Grinding Wheels.}

A sufficient number of signed acceptances having been received this Division announces that the lst Revision Edition of Simplified Practice Recommendation No. 45 Grindirg Wheeds, is now in effect. The combined efforts of the General conference and the first revision resulted in a reduction from approximately 715,200 to 254,000 varieties of grinding wheels, corresponding to an elimination of $64.43 \%$.

\section{Dental Hupo}

Manufacturers of Dental Hypodermic Needles met in liew York, New York, on January 23 under the auspices of the Division of Simplified Practice to consider the practicability of applying the principles of simplification to their products. The conferees drafted a tentative list of sizes and appointed a manufacturers' comittee to prepare a final list which may be used as agenda for the consideration of a general conference of all interests in designing a final Simplified Practice Recommendation.

\section{Malleable Foundry Refractories.}

During the month of February the Standing Committee of the Malleable Foundry Industry will convene in Chicago. Illinois for the purpose of considering a revision of Simplified Practice Recommendation No. 79. The date of the meeting will coincide with the sessions of American Ceramic Week.

\section{Shipoing Tags.}

Upon request of the industry the date for a general conference of manufacturers cistributors, and users, of shipping tags has been post poned until later in the current year. This meeting was originally scheduled for January 25, 1929. 

Commercial Standaras MonthIy - lio. $47-1-$

\section{Benie Cheicks.}

Simpified Practice Recomandation No. Eo, Bank Checks, Notes, Drafts, and Similar instruments has been reafrirmed in its original form by the standing Commitee of the indrstry for another twelve months. A survey condueted prior to the revion meeting indicated that the present measirable degree of adherence to the recommenation is 82.64 per cent. "Iho original schedule, wich effected a reduotion in size frcm thousancs to ono size for eash instrument, was approved by a general conference of all interests meeting in Washington. D. C., on December 4, 1925. That this program has proved cf convenience to the business world is evidence by a promjnent banker vico is convinged that 3 continuance of the present degree of adherence will make possible an annual saving of \$20,000,000,00 for all concerned

\section{Simoljicication Bureau.}

The N. R. D. G. Associztion contempiates the organization ô a bureau to cevote its time to matters concerning Simpification and standardization. On January 23 , a representative of the Division of Simplified Practice attenced a meoting of the Association's special committee, for the purpose of explaining the cooperative serices of the Division of simpiIied Practice in assisting industry to gain sugport for programs of its cun authorstip. The February gathering of the N. R. D. G. Associetion, will further refine the tentative nlan of organizing such a bureau.

\section{Comnasition B? Bckboard}

Simplified Practice Recomendation No.75, Composition BIackboard, has been renffirmed by the Standing Comittee for another tweive months. At the time the recomendarion vas reviewed, it was the uanimous opinion of those in attendance that the program has provea keneficial. The original simplification gromulgated in 1928 reruced the varity in colors, from 3 to 1; widths, from 13 to 8; and lengths from 90 to 13.

Letal Eartitions For Tollats and Sngwers.

A general conference of danufacturers, cistributors and users, held on Ianury is, Washington, D. C. approved a simplified practice rommendation on metal toilet and shomer partitions. The recomendation is to be effective for wer production on Juiy 1 . 1929.

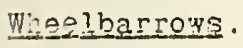

A survey or the sales of various sizes and types of wheelbarrows for tine jears 1927 and 1920 has been completed by a comitiee appointed by the manufaturers. The composte renort of the survey was subuitted to a conference of ali whaelbarow manufacturers at chicaco, Ilinois, this wonth, and initial steps wete taken in anticipation of a general conference of all interests.

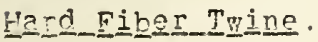

The completion of Simplified practice Receumendation No. 92, on this subzect pas mertioned in an earlier number of commercial standarls ironthiy. It is tho purposs of the twine manufacturers to affix a tag to those of their products wiok conform mith Sing?ified Practice Recomendation No. 92.

Metal

The manufacturers of matal lath hare, since 1924 smployed a wetel tą to icentify the products with Simplified Practice Recommendaion No. 3, Metal Lath. 



\section{Tags and Labels.}

Industry to an increasing degree is adopting tags and catalog reierences as a means of emphasizing the fact that there is extant an appropriate Simplified Practice Recommendation covering their products, the success of which is entirely dependent upon the whole-hearted cooperation of all concerned.

\section{House Organs.}

The house organs of several companies and several trade papers have given added impetus to the promulgation of a simplified program by using replicas of the acceptance blank in their respective publications, as well as running news items regarding the simplification. This has been carried out particularly with reference to Simplified Practice Recommendations No. 89,92 and 98 . The house organs and trade papers realizing that no standard of practice is of any value unless they are known to, and used by, the industry, have given much valuable support to the work, as stated.

\section{USE OF SIMPLIFIED PRACTICE NEWS}

Many inquiries have been received since our January 15, number was released, as to the propriety of reprinting items from "Commercial Standards Monthly" in trade papers and house organs. For the information of all who may be interested, we wish to state that the Department of Commerce approves of such practices. It will, however, be appreciated if credit is give to "The Commercial Standards Monthly" when reprints of original material is used.

\section{STABILIZATION.}

During the past year the War Department has made specific progress in the direction of simplification and stabilization. Officials of the departnent say that economy and efficiency have therefore been prometed. As a result of these efforts toward simplification, the allocated facilities have been reduced during the year from 20,000 to 14,000.

\section{BALANCING}

Saying that "Now is the time for reckoning" the "Mill Suppiies" editorially comments on the need for elimination of failures of the past year. "The vear 1928 is past", remarks the editorial, adding that "in most cases supply houses have taken inventory of stock. They know what their turnover was. They know what their total sales were. They know what their overhead was. They probably know generally what their net profits were. In the end, this latter is the best concrete evidence of the success or failure of the year's efforts.

"If their net profits have been too small, they are probably studying the causes. They may find various factors, such as too great an overhead or too small a margin allowed by some manufacturers, contributed to this condition, but in some instances one of the prime causes will be found to be in the practice of going after volume sales with too little regard for profits whatever the causes, no" is the time to eliminate them, for 1929 has all the earmarks of a year of prosperity". We suggest that industry give more thought, during 1929 to simplified practice.

\section{THE_GREAT ADVENTURE.}

Many explanations are given for the apparently endless prosperity of these United States, says Earnest Elmo Calkins in the hagazine of Business but a principal cause, frequently overlooked, is the fact that American business leaders bring to their work an enthusiasm and 

Commercial Standards Standards Monthly - No. $47-6-$

interest which are not caused or measured entirely by profits. The world is more interesting than it has ever been, dazzling cpportunities break every day, and these men who are too interested to let go are malring realities out of fairy tales and having, as President Roosevelt would have said, a perfectly corlsing time doing it.

\section{PJST OFEICE_SAYES : - 2000 .}

In his discussion of savings effected by tho Post Office Department during the 19z8 fiscal year, the Postmaster General said the department saved $\$ 15,000$ in the purchase of envelopes, due to the fact many of the varieties were consolidated to conform to commercial sizes as well as grades of paper. In 1920 there were more than 300 items listed. For the 1928 fiscal year there were but 80 . He also said that a change in the design of mail bags had saved $\$ 30,000$ a year. The Postmaster General has asked Congree to standardize motor car equipment of the department as well as accumulate a reasonable reserve of such equipment in the postal service so that it will not be necessary to pay rentals for vehicles obtained under contract.

\section{MOTOR TRUCK SIMPLIFICATION}

In a recent address delivered before the Society of Automotive Engineers in Washington, D. C., Mr. Jcseph Bavett, an official of a prominent motor kus and truck company discussed the question "Is one's fleet Standardized?" He said that "many factors entered into the successful operation of trucks, one of which is the simplification and standardization of equipment A diversified inventory loads the shops down, resulting in a rather expensive operation. Neither is a diversified line of equinment interchangeable, so that the large and expensive inventory must be retained, unless the line is simplified."

\section{EETTER MANAGEMENT}

There are better profits through better management, as revealed through simplification, the elimination of waste, more highly efficient personnel, and a finer spirit of cooperation, said Craig B. Hazlewood, Vice President of the Union Trust Company of Chicago, in a recent article appearing in MANAGEMENT REVIEW, - $n$ this article Mr. Hazlewood said that "the amazing spectacle of the youngest of nations in the vanguard of commercial progress pays silent tribute to the creative genius which has so distinguished American business.

"In the face of this remarkable development it is natural, but unfortunate, that tha emphasis be plased upon size and volune, attributes which can never measure up as the ultimate aim of industry. In the fast-runing current of these days, we need to ta'e a new orip upon the practical realities of business, realizing that though re set up the greatest retail business, the largest factory, the biggest jobbing organization in the country and have net profits we have failed to be of permanent service to the public. Fortunate?y, we are now in the morning hours of a new era in scientific management, revealed through simplification, the elimination of waste, more highy efficient personnel, and a finer spirit of co-operation."

\section{SIMDI TFIED INYOICE LEAGUE.}

The Machinery Buildors' Society regorts through its Secretary, W. C. Fulmer, that the Simplified Invoice is coming into ganeral use, according to "The Southwestern Purchasing Agent." Mr. Fulmer reports, "80 per cent of us now use, or intend to use, the Simplified Invoice Form" Results of Mr. Fulmer's survey amorg his members are: 

Commercial Standards Monthly - No. $47-7-$

Now Using the Simplified Invoice $52 \%$

Mill use when present forms are exhausted $28 \%$

Not using, no reasons given $3 \%$

Ni answer received $17 \%$

"S. W. Flagg, Bureau of Methods, General Electric Company, reports that a canvass among 35 representative business asscciations shows 25 definitely interested in the Simplified envoice and active in its promotion. Among the 25 the National Association of Wholesale Druggists reports that nearly 90 per cent of its members are using the form. Another association reports that the form is used by 10 per cent of its members; but better results are expected as time goes on."

Tho "Purchasing Agents" Association of haine has forwarded reports from 75 per cent 0 " ineir members. Such a response is evidence of the keen interest of this group in promulgating the adoption and use of the Simplified Invoice Form.

The New England Purchasing Agents" Association now leads in the number of reports forwarded by its members, with the Purchasing Agents Association of Los Angeles a close second. What is your Association doing to promote the adoption and use of the simplified envoice Form?

The Division of Simplified Practice invites all firms and associations to review their incoming invoices over a period of ten (10) to fifteen (15) days, and then inform us as to the number which conform in all respects to the simplified Invoice Form. Invoices which only partly conform to this standard should not be counted. Our intention is to publish these reports in each issue of The Comercial Standards Monthly. Our purpose is to promote the general adoption of this form, wherever possible and practicable in the movement for elimination of waste. For the current report of the league see Appendix.

\section{COMMERCIAL_STANDARDS.}

\section{J. Fairchild.}

\section{NEWS OF PROGRESS}

\section{Compercial Standards Service.}

There are today many groups of manufactured articles the outward appearance of which is so simila: as to baffle any ready comparison of quality by the large majority of buyers without rosort to elaborate or expensive laboratory tests, and, as a natural consequence, these goods are purchased on a price basis with some regard for outward appearance but with little discrimination as to real quality except when disclosed after repeated and expensive experience. It is a simple matter to compare pricos. The great question in the mind of the buyer today is the question of quality, and every known article possessing unusual quality which is now offered for sale appears to be enjoying a large and satisfactory business.

The great competition today is betwoen industries and it is natural, therefore. if members of a given industry desire to set up a minimum level for their commcdity below which, quality shall not be allowed to fall, in order that the public may buy with assurance and confidence and that the compodity as a whole shall retain the good will and command the respect of the purchaser. This can be cone quick effectively through the assistance of the commercial Standards Service. 

Commercial Standards Monthly - No. $47-8-$

\section{Regain of Mercerized Cotton Yarns.}

A general conference of representative manufacturers, mercerizers, general interests, and users, held in Washington, D. C. January 15, adopted a Recommended Commercial standard for regain of Mercerized Cotton yarns to the effect that mercerized yarns having a regain below $71 / 2 \%$ or above $91 / 2 \%$ shall be adjusted by the seller or buyer, as the case nay be, on the regain basis of $81 / 2 \%$. Such yarns with a regain between $71 / 2 \%$ and $91 / 2 \%$ shall not call for adjustnents between buyer and seller. A regain of $81 / 2 \%$ is equivalent to $7.83 \%$ moisture content.

So many inquiries have been received for an explanation of tho term "regain" that it may be voll to insert the definition adopted by the conference which as as follows:

Regain - The difference between the weight of the material, as is, (a) and the weight in a kone dry condition. (b) expressed as a percentage of the bone dry weight.

The conference set July 1,1929 as the date upon which the recomendation is to become effective and a standing committee was appointed to consider the recomendation annually for revision in order that it may be kept continually in accord with current practice and the advance in the art of conditioning mereerized yarrs. The recommendation has been submitted to all interests for written approval. The following quotation from a letter dated January 23 from the Natinnal Association of Hosiery and Undervear Manufacturers is quite encouraging. having been written subsequent to the conference; "This association is highly pleased witil the work of your department in connection with this matter."

\section{Domestic and Industrial. Fuel oils.}

On January 9 , in Now York City a gensal conference of oil refiners, distributors and consumers, together with the manufacturers of oil burning equipment, voted their approval of the Proposed Commercial Standard for Industrial and Domestic Fuel 0ils, after some slight modifications had been discussed and accepted. The conference was well represented by all interests of the industry and a balanced committee was appointed to consider the need of changes after the specifications are in actual use for one year from the effective date July 1. 1929.

The Recommended Comercial Standard sets tp specific limits for viscosity, distillation range, pour point. flash point, Water and sediment as the recognized criteria for measuring the quality of these fuel oils. It is expected that much of the misunderstanding previously attencing the purchare of fuel oils will be eliminated, since refiners, distributors, and consumers will no longer have to rely on the loose designations of gravity and color heretofore largely used as a basis for sale of corestic and industrial fuel oils.

\section{Mall Paper.}

The Wali Paper Manufacturers Association have requested the assistance of the Bureau of Standards in the establishment of definite grades and quality for wall paper as a means for protecting the purchasor and the reputable producer. The association particularly desires to set up criteria for measuring quality of the stock and the color fastness of the finished paper. A preliminary conference held in New York City on January 24 appointed a comittee to draft tentative specifications for the various grades. 



\section{SPEIIFICARICNS}

\section{A. S. Mc. Mli 1 ister.}

\section{2. "SALVAGE"-}

Waste reclamation has become a big business. It has its own magazine "Salvage", its own extensive directory of dealers; it has a dealers' association, and recently a book of standard specifications for the grading of waste has been published. These specifications should prove helpful to the manufacturer who wishes to dispose of factory wastes to the best advantags .

\section{Procurement Spwoifications.}

A first step in planring for the procurement of the many thousands of items on the procurement list of the army, is the preparation of specifications, said the Assistant Secretary of War in his annul report for 1928, in discussing the war-time procurement work of his office. Standard commercial specifications are used where applicable. In the develcpment of specifications for non-commercial items, care is exercised to assure that the articles can be manufactured in quantity and that no unnecessary construction difficulties are involved. He further added that "obviously, specifications unsupported by an adequate inspection system can not assure us of obtaining the most suitable article for our purpose."

\section{STANDARDEEUIPRENT.}

Excellent progress has been made, by the Committee on Standardization of the American Petroleum Institute, in the formuation and adoption of specifications covering practically every important item or class of equipment used in the drilling and producing of oil. According to Mr. W. G. Slelly of the Skelly Oil Cowpany these specifications and standards vill prove of no value unless the oil. companies put them into use. In a recent article by the editor of "Commercial Standards Monthly" which appeared in many of the trade papers, he said, "The oil industry has done more toward simplification of its supplies than any other industry. The variety of sizes of steel barrels and drums have been reduced under a simplified practice recomendation from 66 to 24 , with resulting increased inter-changeability of items, reduced stocks, and elinination of time lost in delivery, and increased second-hand value,"

\section{MARINE STANDARDS}

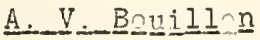

\section{COMMTTPEE_NEWS}

Digest ổ principal activities of American Marine Standares Conmittee during the month of January are as follows:

Report covering the last quarter of 1928 was issued by the Secretary, showing the status of the crganizatiln and work at the close of 1928 to be as follcws:

Membership .................................................... 353

Standards promulgated.................................... 87

A list of printed publications covering the standards promulgated to date: Also alphabetical and classified indexes to the publications and standards were issued to all members and participants in technical activities. 

Comm.srial Standards Ronthly - 20. $47-10 \mathrm{~m}$

The special comithee appointed by the Executhve Board at the November meating to npen the ballots and canvass the vote for election of the Executive Board for 1929 met on Janury 8 and determined that the following had heen eleoted. Kr. Evwin C. Benrett, Naval Archtect. New York. New York: Rear Admiral J. D. Beurat, (CC) U. S. N : Chies fo Bureau of Coostruotion and Repeir. Nayy Department, Pashington, D. C.; Wr F. Foner L. Fergusnn. Fresident and Genera? Nanager, Newport News Shipbulding and Dry Dook Conpany, Nowport News, Virginia; Wr. Theodore E. Rerris, Naval Architect and karine Fngineer, New York, New Lork; Mr. Hugo P. Frear, Vice Presidont, darine Engkneoring Corporation, Philodelphia, Panna ; Captain R. D. Gatewond, (CC) U. S. M. Maneger, Maintenanoe and Repair D1vision, U. S. S. B. Mercharu Fleet Corp. New York.

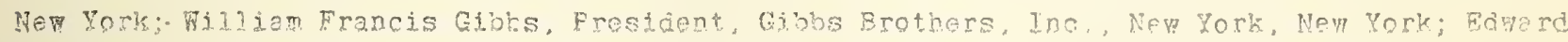
C. Gillette, Superintencent of Haval Construction. Bureau of Lighthouses, Washington, D. C :

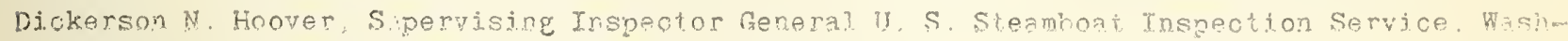
ington, D. C.; Henry C. Huter, Counsel, National Council ne Amerioan Shiphuildars, New Vork New Yor's; Major General Erigas Jadwin. Chief of Bngineers, U. S. A., Mar Department, Washinton, D. C.; Cantain Charles A. MícAljister, Prestcent, Amerionn Burean of Sinipping, New York.

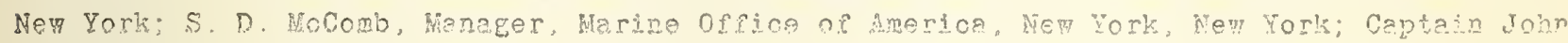

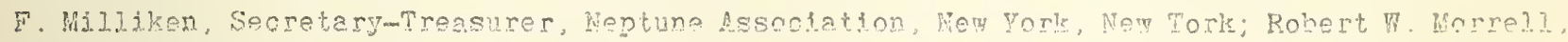

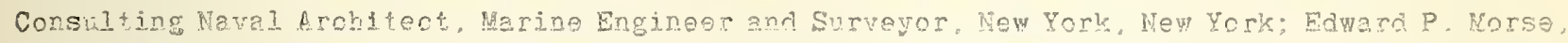
Vice-Fresident, Horse Dry Dock and Repair Company. Brook?yn, New York; E. H. Rigg, Maval. Architect, New York Shipbuilding Company, Camden, New Jersey; Dr. Herbert C, Sadler, Dean of Colleges of Engineering and architecture, University of Wichigan, Ann Arbor. Michigan;

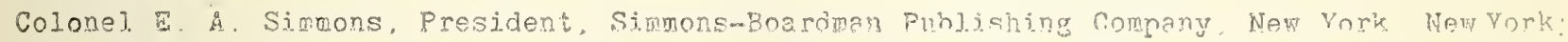
Joseph J Tynan, General hanager. Union Pignt, Betbelehen Shinbulding Corporation, San Franm cisco, Calif.: H. B. Malker, President, American Steamstip Owner's Assocition, Wew York New York.

Preliminary drafts of proposed standard specification for lifeboat disengaging apperatus and of proposed standerd general instruotions for the rat proofing of ships were submited to the memoership and others interested en oritical comment. The following preliminary drafts of proposed standards were submitted to subjoct and technical comittees, viz

Altornative types of mooring pipes of sizes oorresponding to standard sizes of mooring Litts already adopted. Retal stendee and stateroor berths of various types. Care and operm ation of oil-burning apparatus and handing of fuel oil on shins, Manusoripts for printed publicaizons or the Ausc series containing promugated standards wese oompleted and issued for printing as follows:

AMSC-55 - Ship Propollers - Spocifjogtions for builbum propellers; templates for nrom pelier blade planges and tolt holes; snd propeljers cast in one piece. Alisc-56 - Ship Soupper and Drains compristng standards for All weather deck scmpers; deck dreins, plain tupe and trep type; and interchangeable alternative types of cleck drain sirainers.

The Executive Board met in Weshirgton on Jemury 28, but transeoted only a limited amonnt of business owing to unavoideble absence of mombers espocialiy interested in matters presented. It was concluded to adjourn the mesting to a more converiont date and p? ace for al? concerned. This was agreed upon as February 8 , in New York. Announcenent has heon issued accosdingly. A combined report of the pronecoings of hoth meotings will he issued later

A meoting of the membership and partioipants in technical fotivjties tonk place in Washington on Jnnury 29 at, which the chrirman revigmed the progress made by the organizeition and a number of subjects arfecting the sctivithas of the comitien were dischissed Interest. centarad unon the prospective organization of a techninal comithe on port facilites; the extept to which standards ara being use. edr the prospents for promulgating edditional

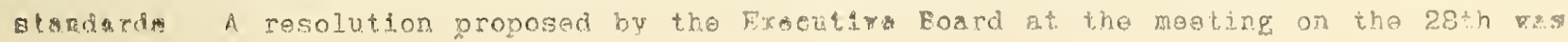



adopted at the meeting on the 29th, to the effect that regular annual meetings of the membership and participants in technical activities heretofore held in Washington during January of each year, are hereafter to be abandoned in view of the fact that the organization is now functioning along definite lines and the Secretary's office maintains constant contact with all concerned.

\section{Editorial. Praise for Commite}

A splendid editorial tribute is paid the work of the American Marine Standards Commitee by "The Marine Journal". In his editorial the witer said "if any one outstanding feature is characteristic of American progress in the industrial world, that feature is standardization. Therefore the best wishes of every one who prays for the day to dawn, when America shall be able to sell ships in competition with the shipyards of the rest of the world should go out to the American Marine Standards Comittee."

\section{DOMESTIC COMMERCE}

\section{TEXIILF_PUBLICATIONS_LISTED.}

The Textile Division of the Bureau of Foreign and Domestic Commerce has just brought up to date its list of Government publications relating to textiles, originally issued in July, 1927. The work of the Bureaus whose nublications are cited is briefly described, and suogestions on how to obtain public documents are included. The list is divided into the following sections: General Publications: Raw Cottcn; Cotton Manufactures, Except Knit Goods and Wearing Apparel; Wool and Hair and Vanufactures Thereof, Except Knit Goods, Wearing Apparel and Floor Covering; Silk and Rayon; Wearing Apparel, Other Than Knit Goods; Knit Goods; Miscellaneous Fibers and Wanufactures Thereof; Floor Coverings; and Dry Cleaning and Laundering Publications. The pamphlet is available for free distribution and may be obtained upon recuest from the Textile Division. Bureau of Foreign and Domestic Commerce.

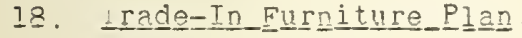

Furniture houses on both the East and West Coasts have built up a traje in, trade-in furniture analogous to the practice of automobile dealers. A customer wishing to buy a new dining-room or bed-room suite turns in the used suite, the new purchase being credited witl an allowance based on a fair valuation satisfactory to the purchasor. The furniture trade-in is then repaired and refinished and sold in a separate store and in a separatebuilding. usually operated as an annex of the main store.

the plan is described in the "Retailer and the Consumer in New England" recently issued by the Domestic Commerce Division. Which may be obtained for lo cents a copy from the Superintendent of Documents, Government Printing office.

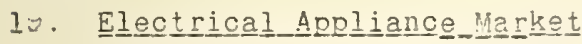

The International Magazine Company, Inc., recently made a study of the market for convenience products such as irons. toasters grills, percolators, waffle-irons, heating pads. and fans, and of labor-saving devices like electric washers. vacum oleaners. ironers. and dish-washers. Location of electrically served communities the buying power of families in those places. the degree of their desire to purchase such products. and the accessibility of retail stores are mentioned as impontant factors in concentrating sales efforts for electrical appliances. It is pointed out that the higher the retail price of the product the more important the larger market centers become because of the relation of family buying power to the price range of the product and the reduced number of medium to high incomes in smaller places. 

The percentage of "saturation" of electrical appliances, based on 17,596,390 wired homes, has been worked out for the various electrical appliances as follows: Irons 87: vacuum cleaners, 39; clothes washers, 28; toasters, 26; room heaters, 15; percolators, 10; hot plates and grills, 9; heating pads, 8 waffle irons, 5; and floor polishers 2. Concentration of 55 per cent of the nation's total wired homes in 640 cities designated as "Principal Trading Centers of the United States" is pointed out. In these centers are 69 per cent of all family incomes of $\$ 3,000$ and over, which offer the largest market for all "hedium to High" priced electrical appliances. The 2,944 "Subordinate Urban Places," with a population of 2,500 and over, have 21 per cent of the total wired homes of the country. The rural market, although it comprises 45 per cent of the population, is third in importance because comparatively few rural families are served with electricity and the "Medium to High" income group of rural families is very small. The concentration of sales operations, jncluding advertising, in the light of these facts, is recommended as logical when the product is thus weighed against the need and the purchasing power of the consumer.

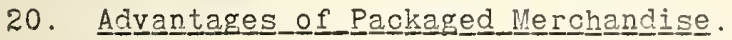

Aside from the generally recognized advantages of packaged merchandise to the middlemen and retailer, there are distinct advantages to the manufacturer, some of which are listed in "Packages That Sell by R. B. Franken and C. B. Larrabee. Among these are: (I) Advertising value, making posible the lise of trade-marks and stimulation of consurer demand (2) preventing substitution; (3) ease of handing, storing, and transporting, protecting goods against breakage, spoilage, spillage, evaporation, and pilferage: (4) assurance that products reach the ultimate consumer in the condition in which they leave the factory; (5) enabling standardization of quality and quantity of the product; (6) making possible the sale in small units of many products heretofore sold only in bulk; (7) fostering large-scale concentration, simplification standardization, and specialization; (8) educational possibilities of paolage inserts in showing new uses for products; and (9) facilitating price maintenance.

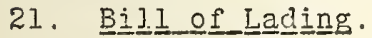

"Uniform Through Export Bill of Lading" is the title of Trade in information Bulletin No. 593, recently issued by the Bureau of Foreign and Domestio Commerce of the U. S. Department of Commerce. It is written by $A$. Lane Cricher. Assistant Chief, Transportation Division of the department, to answer the questions raised concerning the use and the practicability of the uniform through export bill of Lading. Copies may be secured from the Superintendent of Documents, Government Printing Office, Washington, D. C., at 10 cents a copy.

\section{BUILDING AND HOUSING}

\section{J. F. Taylow}

\section{Plumbining_Legisliation.}

Considerable activity in the preparation of state plumbing legislation at the present time has come to the attention of the Division of Building and Housing. Requests have been received from health departments in a number of states for the recommended minimum requirements for plumbing prepared by the Sub-comittee on Plumbing of the Department of Commerce Building Code Committee. These recommendations, based largely on the results of tests at the Bureau of Standards, have already been used as the basis for plumbing requirements in eight states, as well as in many cities. 



\section{RESEARCH}

\section{Research as_a Businesess_Help.}

Research is no longer considered a business pilantropy. It is no longer a side issue or hobby to be supported or neglected in the degree that money is donated by its frienis. On the contrary, as recently stated by Irving Langmuir; "The leaders of incustries are frecuently conscious of the need of improvement in their processes and even of the need of new discoveries or inventions to extend their activities." Research is the modern tool by which to work out commercial success in any industry.

But beyond the commercial incentive to survive under highly competitive conditions thero are broader aspects of research that affect kusiness directly. Heretofore the world has been kuilt and operated largely through the wasteful use of raw natural resources. Wany of these have not been reduced in roume, kut despite this, man made projucts derived from researches have suppied the public demand with cheaper and better procucts than those made from the original materials.

Under the spur of a diminished supply, research comes into being to replace old materials with new, and business today realizes that only through scientific research can it remain prosparous under modern conditions. No organization economies can replace research as a direct method for maintaining kusiness success.

\section{Establish}

Establishment by the Textile Bag Manufacturers Association of a research department to develope new kinds of textile bags and to investigate the possibilities of new uses, is reported in the "DaiIy News Record of Decemcer 19." Several testing machines have been installed to secure greater efficiency in the manufacture of cotton and kurlap kags. Drop tests are also planned. This step follows the Association's recent advertising crive to create a greater demand for textile bags.

\section{Resea arch_and_Advertising.}

According to Malcolm Nuir, President of the kcGraw-Hill Publishing Co. "sonething more than accident has created that great national wealth which the world calls Ainerican prosperity; something wore than mere wishing for riches has made the past clecade since the Arristice so fruitful in terms of re-created inclustrial wealth andsupremacy. One of these "somethings" has been the partnership ketreen research and advertising. Research today is a field which meets with every encouragenent - spurred on by the knowleage that the lag between discovery in the laboratory and actual sale of the product is being rapidly reduced to a minimum. Advertising today is a mighty sales machine, a great propelling force for industry in its movement forward to the new objectives and the larger markets. It is the close liaison and the spirit of understanding between the two which has contributed so tremendously to our national wealth and well being and given us commercial pre-eminence."

\section{Vision.}

Expressing the belief that "the bigger viewpoint is necessary to proper lusiness progress," Fred Counterman, recently wrote on this subject in MILL SUPPLIES, as follows: "Chained to the present with tiny links of petty cetail and monotonous routine, many kusiness minds are denied the opportunity of far-distant vision. While their futile strivings serve merely 

to ground them more deeply in the rut they have trudged for years. With their eyes resting on the simplest and nearest problems, vision of opportunities that reach out ahead of them is at best blurred and clouded. We easily become habituated to the narrow limits of our own little courtyard, and lose all desire to climb to the tower and look beyond. The executive who thinks of his business as jogging along through the years at the same pace it has been following. While he satisfies himself with the hope that competition will let him alone, will never attain the heights. Failing to visualize future potentialities, he is incapable of rising to then. The time to get the biggor vision is now before ve become so nearsighted wo can not see beyond our office walis."

27. iidgen_Treassuㅗ.

"Wearch for hidden treasure in the olden days of pirate bold and buccaneer held no more thrilling variations than the uodern search for that elusive point of profitable volume." says Harry R. Tosdal, Professor of Warketing, Harvard University,

Friting on this subject in THE MAGAZJNE OF BUSINESS, under the tille of "Less Business More Profit", he said. "For every company under given conditions there is a volume of sales which will furnish the most satisfactory profit goal. It is large enough to furnish gross margin, but not too large to make expense excessive. This mythical point can be approximated by concentrating on the most profitable customers by the wost profitable selling methods and protecting gross margin from being annihilated by short sighted price policies. In developing these ideas, the manufacturer needs to understand something of the conception of the "Natural" market, the market whose location and size is such that it yields the maximum net profit. Business will be better, costs of distribution will be reduced, the public vill be better served when business discarcis the assumption that a cure for, "profitless prosperity". is greater sales volume."

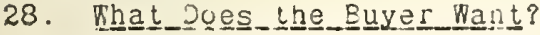

In a discussion of "What Does the Buyer Want?" in PRINTERS' INK PEEKLY G. A. Nichols said that "putting the production cart before the research has disastrous effects, even when tied to the hitching post of high-pressure advertising. This fact has been proved timo and agaia, and yet there are manufacturers who still persist in arbitrarily flooding the market with uneranted merchandise. The buyer is the one first to bo consicered, his needs, desires and habits must be the guiding factors. The only way to find out what he vants is to go where be is and study him. But this the average manufacturer seems curiously loath to do. Such lack of respect for the ultimate consumer is highly dangerous, for general advertising has taught him wuch. In addition, his life is a never ending struggle to stretch his income to its maximum buying power. which has sharpened his wits and made him price educhted and advertising conscious. Preliminary diagnoses of market trends and inuividual needs would reduce selling costs and establish profits on a healthier basis."

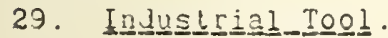

Under the heading of "The Institute Becomes an Important Industrial Tool" in ADVERTISING AND SELLING, J. George Frederick, remarks that "in the dyas when large industrial groups cathered bother only socially and when prohibition of discussion of business ras the accepted tradition. competitors in the same line of business had to be hypnotized before they rould consent to place their feot under the same table. It has taken 20 years to bring together sufficient background, activity, and intelligent cooperation to make possible an institute in an industry, but today it is one of the wost effective tools available for unifying industrial action and advancing the interests of an industry as a whole. The institute as a method is no panacoa, contains no wagic in itself. It is rather an aggressive 

Commercial Standards Monthly - No. 47 -15-

organization with varied aims, the chier of which lie in the direction of videning consumption through advertising, and curing some of the basic ills of marketing and distribution.

\section{0. "Market Research Agencies."}

The 1928 Edition of "Market Research Agencies," just issued by the Domestic Commerce Division, is the most complete market research source book yet compiled. The purpose of the publication is to present a record of market research investigations - completed, current, and contemplated - with the hope of curtailing duplication of research and thereby eliminate waste.

An innovation in this third edition is a section on publishers of trade directories of whom 79 are given besides the 22 publishers whose books bearing on market research are listed. Increased attention has been given this jear to the marketing of producers' goods and services. Direct contact with state government bureaus, educational institutions, and agricultural experiment stations has made the references to those organizations more complete and more accurate than heretofore. As in the 1927 edition, the section on commercial organizations includes the market research activities of advertising agencies, business services, chambers of commerce, cooperative marketing associations, individual businesses, magazines, newspapers, and trade associations.

"Harket Research Agencies" is available for 15 cents a copy from the Superintendent of Documents, Government Printing Office, or from any District Office.

\section{UTILIZATION OF WASTE.}

\section{Waste Pars in Some Ways.}

With the demand for economy increasingly a factor in the cnrush of industry little is wasted nowadays. Profitable businesses are built upon by-products and materials that once were thrown into the discard. No longer are sawdust, waste oils, scrap iron and miscellaneous factory debris cast aside to be forgotien. Junk dealing and rag picling are highly organized businesses. According to a recent governmental report, Spain, one of the leading markets for American rubber, is importing old tires, discarded rubber shoes and scrap and reclained rubber of all. descriptions to the extent of more than $\$ 1,000,000$ yearly. Pneumatic casings are transformed into rubber soles that the pasants of the hills may be durably shod for rough going; old cushion tires are converted into rubber heels, while worn out tubes go through the mills to energe in the form of toy balloons, garters, belts and whatnot. They say in the stockyards that everything is used but the pig's squeal. It is not far from being true.

\section{ELIMTNATION OF WASTE.}

\section{Look Back = Ahead.}

As day after day projects itself on the screen of life, there is pieced together a film of untold wealth and ever-videning horizons, writes john Hays Hamond in "Naticn's Business" on the subjeot "A Look Back and Ahead." Mr. Hammond said that it is to avoid the danger of becoming blase and forgetful of our responsibilities and obligations in the fact of such prosperity that frequent and searching introspection is more and more prescribed. The most superficial of these survers will show real wages to be 50 per cent higher than before the war, output incredibly increased through the advent of labor-saving machinery, education thoroughly democratized, and living standards above anything dreamed possible. 

Commercial Standards Monthly - No. $47-16-$

Cne of the most hopeful signs of the times is a higher standard of business ethios the recognition by business of its obligations to render public service to its custcuers. Thus, all about us are evidences of recent accomplishment, of unexampled fruition. The United States is coming into its own, economically, politically, socjally, spinitually. It is the greatest going concern of all the ages and is today, from the standpoint of the past, at its best. There is every reasonable expectation, however, that tomorrow will be greater thar today, that Anerica will continue her course to even greater prosperity and finer accomplishment.

\section{Reduction of Faste.}

Through waste reduction may sesm to zco like a threadbare subject it is one that is getting new attention now and from different angles, says "packages" editorially on the subjeot of "Waste Reduction." Also, as buiness men come to the end of the year season review past doings and plan for better times the next year, there vill be an carnest centering of attention on lowering costs ancimproving efficiency trrough waste recuction.

"Paolrages" emphasizes the point that this doesn't mean merely reducing waste and utilizing waste of raw material in the factorios. That, of course, is part of the program, and has been the outstanding part in the past. There are many other forms of waste, howevor. coming in for attention now which have been overloosed in the past. These incluce wasteful efforis in selling, wasteful methods in accounting and in handling of material through tho factory, and things of that kind. It even include waste incident to cross hauling and unnecessary shipping.

Waste efrort in selling is getting its share of attention now, too. Also it is being found that there is woeful waste comes through too much duplication of salos effort by individual manufacturers. Asd there vill follow in time cooperative or group selling to eliminate rome of the waste and trim some of the cost. It is not only coming to the wooden package industry but is already being featured in many other industrial lines where, it is being pointed out, that there is plenty of compeition between the offerings of different products without so much competition in the selling game between producers of similar rod duots. Su in the drive for waste reduction and plans for the new year, it is a safe prophecy that a goodly share of attention will be centered upon reducing vaste incident to selling the product.

34. Urges Waste Reduction.

The National Tire Dealers' Association and manufacturers have got to plan out a system of distributicn that will eliminate unnecessary waste, recently declared Frederio C. Hooc? President of the Hood Rubber Co. He said that one of the industry's wastes is in the dcpreciation of stocks, both through price declines and because of obsolete sizes. Commenting on $\mathrm{Mr}$. Hoods İmarls, "Tires" said editorialiy he had struck at the crux of the present sitwation in the tire business when he urgeb reduction in wastes of distribution and ciher wastes by dealer and manufacturer.

\section{Booklet on Lumber.}

The Nationel Comititee on Wood Utilization announces the release of the distributors' editicn of the bulletin "Seasoning, Handing, and Care of Lumber". Copies at 20 cents each, may be secured from the Superintendent of Documents, Government Printing Office, Washingtcn, D. C. 

Commercial Standards Nonthly - No. $47-17-$

36. New Publication

Send orders for publications under this heading with remittance, only to the Superintendent of Documents, Government Printing Office, Washington, D. C. Subscription to Euroal of Standards Journal of Research \$2.75 per year (United States and Canada, Cuba, hexico, Revfo ncliand, and Republic of Panama; other countries $\$ 3.50$.. Subscription to Technical Hews Bulletin 25 cents per year (other countries, 40 cents) Bureau of Standaras Jolirnal of Research. Vol. 2, No. 1, January 1929 (By subscription only) Research papers. (Reprints from Journal) RP 37. Fire resistance of hollow load bearing wali tile; S. H. Ingicerg and $H$. D. Foster. Price 75 cents. Technical News Bulletin. RNBl41. Technical News Bulletin, January 1929 (By subscription only).

37. Epppersix.

Sinplified Invoice League - Reports received from January I to January 25 . $1929 \ldots \ldots \ldots \ldots$. Company Period checked Simplified of

Boston \& Albany Railroad

Eoston, Mass.

The Foxicoro Company. Boston, Mass.

Chicago Rapid Transit Company, Chicago, III.

Fellows Gear Shaper Company. Boston, Mass.

Baxter D. Whitney \& Sons, Inc., Boston, Mass.

E. Corey \& Company, Portland, Me.

Hygrade Lamp Company.

Boston, Mass.

Boston \& Maine R. R. .

Boston, Mass.

Sullivan Machinery Company,

Eoston, Mass.

Hunt-Spiller Manufacturing Corp.

Boston, Mass.

Cumberland County Power \& Lt, Co.,

Portlana, Me.

Vireless Specialty Apparatus Co..

Boston, Mess.

Massachuseits Lighting Cos.,

Boston, Mass.

A. C. Lawrence Leather Co.,

Boston, Mass.

Holtzer-Czbot Electric Co..

Boston, Mass.

Carter's Ink Company,

Boston, Mass.

Hollingsworth \& Vose Company,

Bosion, Mass.

New Orleans Public Service Co..

New Orleans, La.

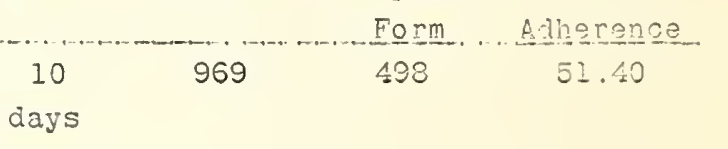

45.00

$\begin{array}{llll}1 & 814 & 328 & 33.73\end{array}$

week

10

days

15

38.00

38.00

days

1

month

10

days

3

days

9

days

2

weeks

15

days

2

weeks

10

days

2

weeks

2

weeks

15

days

10

days

15

3000 *

162

35.57

111

31.00

29.00

584

27.70

27.00

425

107

25.17

657

164

25.00

23.40

2000

19.00

16.66

15.00

days 

Comercial Standards Monthly No. 47 -18-

1i. F. Sohnafil \& Sons Corp.,

Boston, liass.

15

days

15

days

15

dajs

15

days

15

days

15

ciays

10

cays

15

days

15

days

18

days

12

cays

10

days

15

days

10

days

18

days

6

clays

10

clays

2

weeks

10

days

1

week

1

month

15

caijs

2

weets
14.00

245

34

13.87

13.50

284

37

13.02

13.00

324

42

12.85

12.00

3595

402

11.10

11.00

11.00

713

73

10.24

176

10.22

10.00

10.00

136

13

9.50

9.00

500

40

8.00

52

4

8.00

7.66

447

7.15

32

1352

96

7.10

6.50

6.00

6.00

Wm. Carter Co.

Boston, Mass. 

Commerce Standard Monthly - No. 47--19-

\begin{tabular}{|c|c|c|c|c|}
\hline Company & Period & $\begin{array}{l}\text { Invoices } \\
\text { Checked }\end{array}$ & $\begin{array}{c}\text { On } \\
\text { Simplified } \\
\text { Form }\end{array}$ & $\begin{array}{c}\text { Per Cent } \\
\text { of } \\
\text { Adherence }\end{array}$ \\
\hline $\begin{array}{c}\text { Forbes Lithograph Mfg. Co. } \\
\text { Boston, Mass. }\end{array}$ & $\begin{array}{c}18 \\
\text { days }\end{array}$ & & & 6.00 \\
\hline $\begin{array}{l}\text { Pacific Mills, } \\
\text { Boston, Mass. }\end{array}$ & $\begin{array}{l}15 \\
\text { days }\end{array}$ & & & 6.00 \\
\hline $\begin{array}{l}\text { Stevens Walden Worcester, Inc., } \\
\text { Boston, Hass. }\end{array}$ & $\begin{array}{l}10 \\
\text { days }\end{array}$ & & & 5.00 \\
\hline $\begin{array}{l}\text { United Electric Rys. Co., } \\
\text { Providence, R. I. }\end{array}$ & $\begin{array}{c}15 \\
\text { days }\end{array}$ & 803 & 32 & 3.99 \\
\hline $\begin{array}{l}\text { Rhode Island Pur. Agents Assn, } \\
\text { Providence, R. I. }\end{array}$ & & & & 1.43 \\
\hline $\begin{array}{l}\text { City of Portland, } \\
\text { Portland, we. }\end{array}$ & $\begin{array}{c}25 \\
\text { days }\end{array}$ & 2500 & 3 & .11 \\
\hline $\begin{array}{l}\text { H. C. Baxter \& Bro. } \\
\text { Brunswick, Me. }\end{array}$ & $\begin{array}{c}1 \\
\text { month }\end{array}$ & 40 & 0 & .00 \\
\hline $\begin{array}{l}\text { Pownal State School. } \\
\text { Pounel, Me. }\end{array}$ & $\begin{array}{c}15 \\
\text { days }\end{array}$ & 252 & 0 & .00 \\
\hline
\end{tabular}

* Approximate. 
